\title{
A contentious business: Industrial patents and the production of isotopes, 1930-1960
}

\author{
Simone Turchetti \\ Division of History and Philosophy of Science (HPS), University of Leeds. \\ simone.turchetti@man.ac.uk
}

Dynamis

[0211-9536] 2009; 29: 191-217
Fecha de recepción: 22 de febrero de 2008

Fecha de aceptación: 4 de abril de 2008

SUMMARY: 1.- Introduction. 2.-A statistical survey. 3.-The isotope business before the war. 4.-Patents, isotopes and the war. 5.- The Patent Compensation Board (PCB) activities. 6.-Britain and Canada. 7.-Conclusions: the contentious business.

ABSTRACT: This paper analyses the role that patents played in the establishment of the isotope industry. In the first part I survey the number of issued patents on the production of isotopes, also arguing that the isotope industry was typified by inadequate patenting activities. Then I examine the factors that hindered these activities by looking at the history of industrial patents in the establishment of the isotope industry. I especially focus on the consequences of the Manhattan Project on patent legislation. As the Atomic Energy Act (1946) made the isotope industry a monopoly of the US Atomic Energy Commission (AEC), it contributed to transform the trading of its relevant patents in a «contentious» business. Since then, inventors and assignors already in possession of isotope production patents could only claim compensation to the AEC, which was authorised to seize them. And those who might have outlined new inventions were now deprived of the economic incentive to do so, being prohibited from free-trading them in the international market.

PALABRAS CLAVE: Patentes, Comisión de Energía Atómica, Oficina de Compensación de Patentes, Enrico Fermi, Ley de McMahon, producción de isótopos, Philips.

KEY WORDS: Patents, Atomic Energy Commission, Patent Compensation Board, Enrico Fermi, McMahon Act, isotope production, Philips. 


\section{Introduction}

The production of isotopes became an industrial venture in the nuclear age, when this manufacture proved both industrially viable and commercially profitable $^{1}$. From the late 1940s, sales of isotopes grew; their industrial applications multiplied; and research publications proliferated in technical journals. Using conventional models describing the diffusion of technological innovations, one may even argue that this is the period when isotopes, as technological artefacts, ascended their «s-curve» ${ }^{2}$.

However, the foundations of the new isotope industry were laid on a few industrial patents, and if one examines on these patents, the industry's circumstances can be viewed in a different light. From the 1940s they sparked important legal disputes between inventors, patents' owners, and manufacturers and did not ensure profits in terms of royalties accordingly with the traditional economic rules of the patent system. Moreover, until the 1970s, the number of new patents describing methods and instruments to produce isotopes was unsatisfactory if compared both with the number of publications on isotopes, and with patenting activities in similar industrial sectors. Thus, the new and prosperous industry of isotopes seems to have developed in anomalous conditions which especially affected technological innovation and intellectual property rights relations. How can historians address this anomaly?

Unfortunately, the historiography of science and technology has so far neglected these circumstances. Some historians have used data on industrial patents to investigate the economics of the patent system as

1. This work is based on material from the following archival collections: Collezione Nuovo Amaldi (from now on CNA), Archivio Amaldi, Instituto di Fisica dell'Università di Roma, Rome, Italy; Enrico Fermi Papers (EFP), Special Collection Research Center, University of Chicago, Chicago, US; the AEC papers at the US National Archives (NARA), Maryland (US); the British National Archives (NA); the Direzione Generale Affari Economici (DGAE) papers of the Italian Ministero degli Affari Esteri (MAE).

2. Everett M. Rogers argues that the rate of adoption of new technologies can be represented by an s shaped curve typified by slow growth, rapid diffusion and leveling off. I must stress that I am using here Roger's model only in a descriptive (rather than prescriptive) form. I am thus not suggesting that the model works for the diffusion of all new technologies. See Rogers, E. M. Diffusion of innovations. New York: Simon \& Schuster; 1962 (reedited in 1985). 
well as the economic prospects of discoverers and inventors ${ }^{3}$. Their data have also helped in understanding corporate strategies that accompany the establishment and consolidation of industrial research, and to reveal the corporations' attempts to gain control of new markets ${ }^{4}$. Some studies have focussed on the role of patents in physical sciences, yet none has specifically looked at the isotope industry ${ }^{5}$. Moreover, no study appears to have argued that in some specific circumstances the growth of an industrial sector may impoverish its patenting activities.

This is exactly what this paper looks at. I suggest here that the isotope industry followed patterns alien to the traditional technological development typifying the corporate economy. I argue that these patterns were in place only in the pre-war years, when industrial patents were effectively used to harness control of a nascent technological market centred on isotopes. However, it is only during the 1940s that the industrial production of isotopes

3. On patents in general see: Kaufer, Erich. The economics of the patent system. London: Harwood; 1989; Etzkowitz, H.; Webster, A. Science as intellectual property. In: Peter, J.; Markle, G.; Jasanoff, S.; Pinch, T., eds. Handbook of science, technology, and society. Beverly Hills: Sage; 1994, p. 480-505.

4. For patents in industrial research see: Reich, Leonard S. Research patents, and the struggle to control radio: A study of big business and the uses of industrial research. Business History Review. 1977; 6: 208-235; Reich, L. The making of American industrial research. Science and business at G.E. and Bell, 1876-1926. Cambridge: Cambridge University Press; 1985; Bowker, G. What's in a patent. In: Bijker, W. E.; Law, J., eds. Shaping technology/building society. Studies in socio-technological change. Cambridge, Mass.: MIT Press; 1992, p. 5374; Leslie, Stuart W. The Cold War and America science. The military-industrial-academic complex at MIT and Stanford. New York: Columbia University Press; 1993; Edgerton, D. E. H., ed. Industrial research and innovation in business. Cheltenam: Elgar; 1996. On patents and biomedical research see: Rasmussen, Nicolas. Of «small men», Big science and bigger business: The Second World War and biomedical research in the United States, Minerva. 2000; 40: 115-146. For an exam of legal controversies centred on patents see: Kevles, D. V. A History of patenting life in the US with comparative attention to Europe and Canada. EU Report to the European Group on Ethics in Science and New Technologies. Bruxelles; 2002. See also Washburn, Jennifer. University Inc. The corporate corruption of higher education. New York: Basic Books; 2004, p. 60-69.

5. See for example: Heilbron, John L.; Seidel, Robert W. Lawrence and his laboratory. A history of the Lawrence Berkeley laboratory. Vol. 1, Berkeley: University of California Press; 1989; Lassman, T. C. Industrial research transformed: Edward Condon at the Westinghouse Electric and manufacturing company, 1935-1942. Technology and Culture. 2003; 44: 306-339. On the role of patents in physical research see also: Galison, Peter; Hevly, Bruce; Lowen, R. Controlling the monster: Stanford and the growth of physics research, 1935-1942. In: Galison, P.; Hevly, B., eds. Big science: the growth of large-scale research. Stanford: Stanford University Press; 1992, p. 46-77. 
enormously raised its commercial potential. And as this happened within the context of the atomic bomb project, the trading of patents was restricted by new military regulations. In the post-war years, new patent provisions allowed the AEC to seize industrial patents effectively shaping the isotope industry as a state-controlled monopoly. As the various strands of the isotope industry conflated into a monopoly, they also deflated traditional patenting activities centred on corporate activities. And they introduced entirely new types of intellectual property rights relations administered by governmental nuclear agencies.

In order to explain these circumstances, I provide some statistical data on patents in the isotope industry. I then consider the role of these patents in the pre-war years. Next, I look at the impact of the atom bomb project on patent legislation. I finally consider the legal controversies engendered by this new legislation.

\section{A statistical survey}

The quantitative dimension of patenting activities in the isotope industry can be assessed by looking at the number of issued patents on isotopes and methods (or instruments) for the production of isotopes. Using the database of the European Patent Office, I have considered two cohorts of patents: those in which the words «isotope» and «isotope production» appears either in the title or in the abstract. I have then calculated the number of issued patents in the US, Canada and Britain ${ }^{6}$.

The results show that before WWII the number of issued patents on isotopes remains below 10 for every four years. Between 1958 and 1974 there is a significant growth of patenting activities that leads issuing an average of about 500 patents every four years worldwide. An analysis of the distribution of these patents across nations shows that before 1970 only the patent offices of Britain, the US and Canada issue patents on isotopes. In

6. Data from EPO is available at http://ep.espacenet.com. These three countries issue almost 100\% of new patents between 1930 and 1970. My survey has limitations as it does not consider patents that may have been produced without necessarily using the term «isotope» but synonyms (e.g. artificial radioactive substances) or referring to the instruments of production (e.g. cyclotrons; nuclear reactors). However, we shall see that the historical investigation in the following paragraphs corrects these deficiencies. 
Graph. 1. Number of issued patents including the word «isotope» (1930-2002)

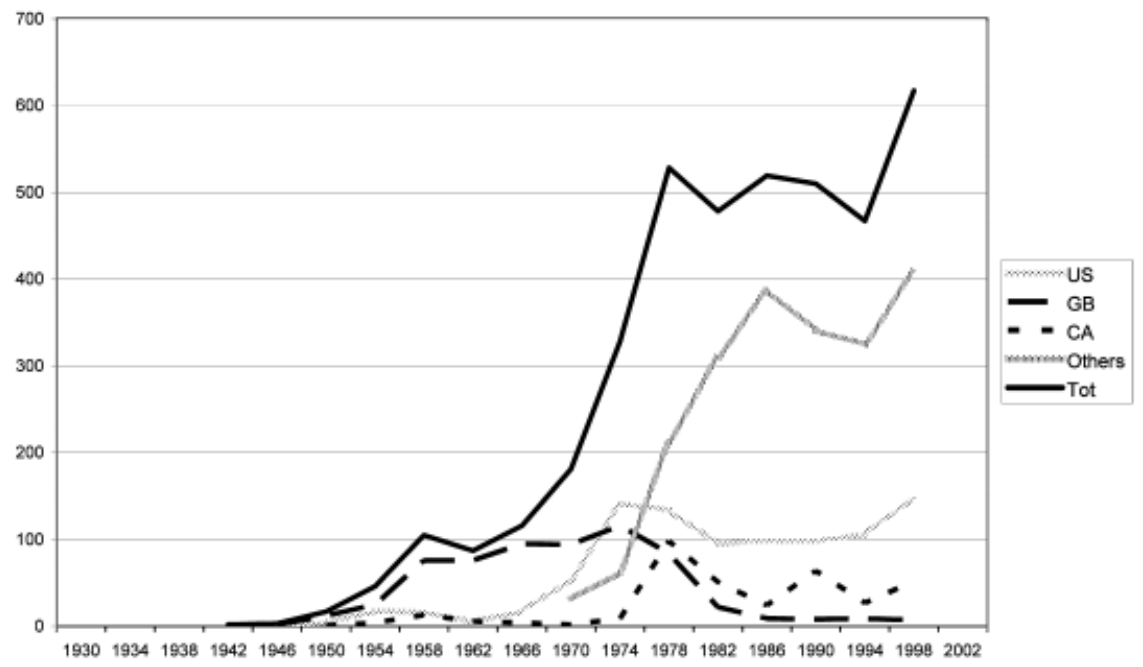

Souce: Europeam Patent Office, see n. 6.

Graph. 2. Number of issued patents including the word «isotope production» (1930-2002)

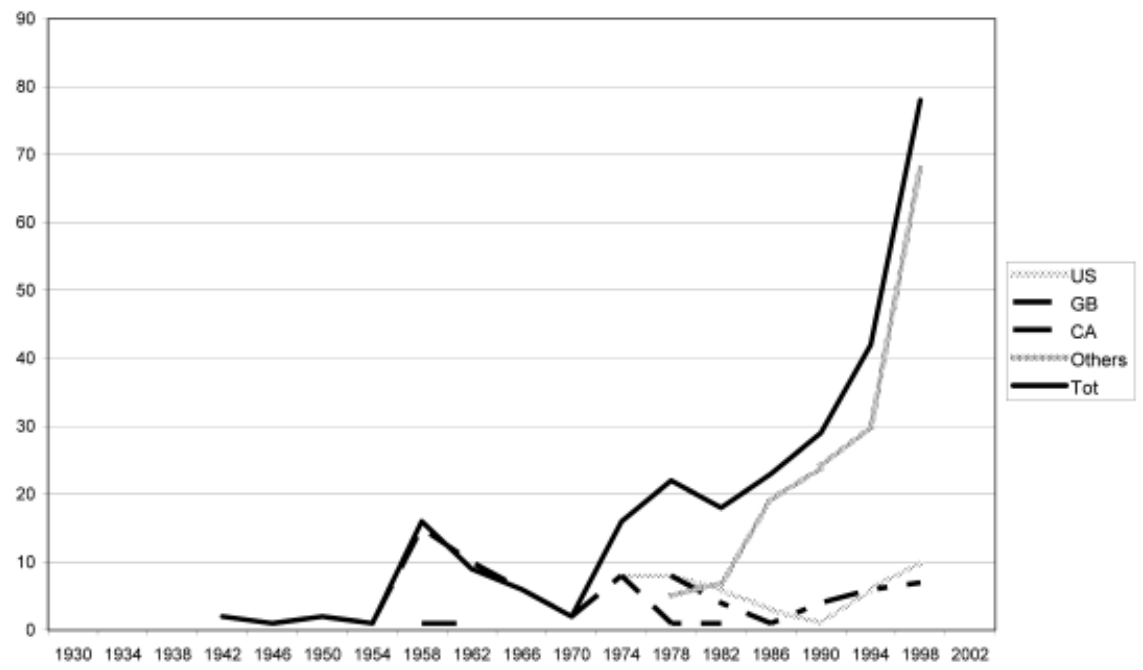

Souce: Europeam Patent Office, see n. 6. 
this period, the British patent office releases $80-90 \%$ of all issued patents. Canada and the US follow with an average of about 10 patents every four years. Towards the 1970s, the leading role of Britain in delivering patents on isotopes dies away, whilst that of the US and Canada remains fairly marginal. From the 1970s, other countries such as Japan and Germany become more prominent in these patenting activities.

The cohort of patents on «isotope production» shows that only a limited number of patents on isotopes deal specifically with the production of isotopes. The first cohort is made out of about 4000 patents, whereas the second only 300 of these patents (4\%). Issued patents on isotope production never surpass the number of 100 for each four-years interval, and their number steadily remains below 50 for most of the periods concerned. The trends shown for the first cohort (inadequate release of patents; leading role of Britain in the early years; and Japan and Germany after the 1970s) are generally confirmed by the second. The most striking element of contrast between the two cohorts is that no patent on isotope production seems to have been released in the US before $1974{ }^{7}$.

These data suggest that the isotope industry lacked innovation channelled into traditional patenting activities. Presumably, this deficiency also affected financial activities centred on industrial patents. In order to understand whether this inadequacy extended to similar technological sectors, I have considered the number of patents on isotopes in the light of the overall number of patents issued in nuclear science and engineering ${ }^{8}$.

The results show that the number of issued patents on isotopes and isotope production continues to be only a small proportion of those in nuclear science and engineering. This data highlights that promising industrial applications deriving from nuclear science and engineering did not especially focus on isotopes, and that isotopes were rather marginal to patenting activities in this technological sector. This resistance to produce patents on isotopes and isotope production is surprising especially if one compares these data with those that typify sales and publications in the

7. This is a problematic data that the will be address in the following paragraphs.

8. Sector G21 in the ECLA classification. ECLA is the European classification system outlined by the European Patent Office (EPO). As isotope research encompasses many different technological sectors, using sector G21 may appear controversial. However, the survey on several patents describing isotopes or isotope production shows that most of them belong to this category. 
Graph. 3. Number of pantents on isotopes in ECLA classification (1930-1998).

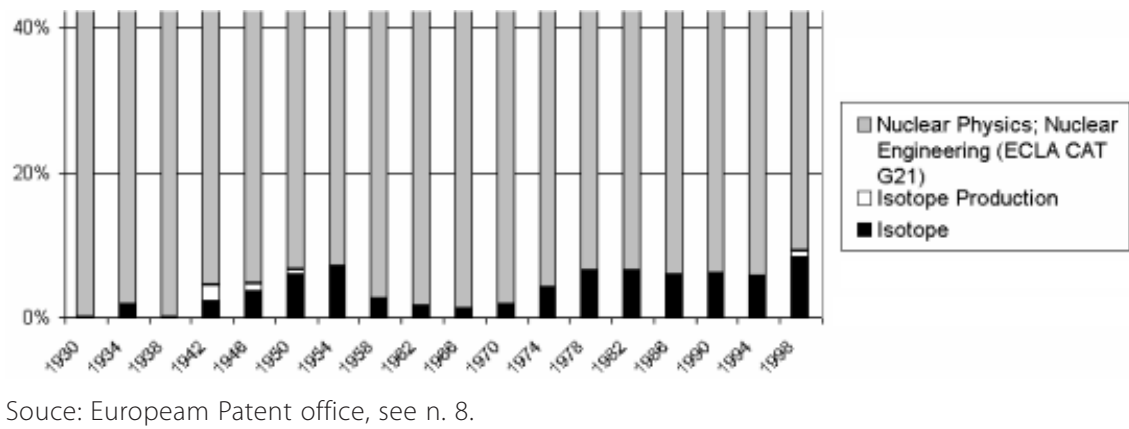

field during the same period. The contrast suggests that only a few patented processes conceived at early stages of industrial research continued to be used in the isotope industry. It also tells us that those investigators who promoted research on isotopes were very eager to publish their results, but far less so to engage with patents ${ }^{9}$.

On the whole, these data clearly highlight the existence of important factors alien to traditional socio-economic dynamics of industrial development that, even when the industry gained momentum, made it difficult to issue patents on isotope production. In order to understand what these factors are, I now turn to the history of some important patents used in the isotope industry from its infancy to the 1960s.

\section{The isotope business before the war}

In the pre-war years, a handful of investigators specialising in radioactivity research sought innovative methods to manufacture isotopes. Patenting activities played a key-role in their scientific endeavours, linking their work with the industrial world. The promise of widespread use of isotopes also engendered commercial rivalry between inventors and industrialists alike. By then, isotopes were being used in medicine and, to a limited extent, in

9. See the articles of Néstor Herran and Angela Creager in this volume. Herran shows that between 1960 and 1964 isotope science articles almost double from 6000 to 12000 yearly. By contrast isotope patents remains at the level of 100 for each four-years interval. 
chemical research. However, these patented methods ruled out a production of isotopes on a large (industrial) scale. And the economic returns that the marketing of isotopes generated were insufficient to promote an extensive trading of patents ${ }^{10}$.

In the 1930s, following the pioneering work of Ernest Rutherford at the Cavendish Laboratory, European and American investigators designed new instruments for the «transmutation» of chemical elements. These chiefly focussed on bombarding chemical elements with highly energetic particles (chiefly protons) in order to induce their transformation into isotopes. One of the first who sought to patent apparatus allowing transmutation processes was the director of the Radiation Laboratories at Berkeley, Ernest O. Lawrence. As shown by Heilbron and Seidel, Lawrence designed a new high-tension machine, the cyclotron, to successfully radio-activate various elements ${ }^{11}$.

The patent on Lawrence's cyclotron was issued in 1934 following a new market strategy of his patron. Lawrence's research was supported by the Research Corporation. In the 1930s, its new director Howard Poillon, had become more aware about the industrial uses of Lawrence's machine because the physicist had successfully managed to produce sufficient amounts of radio-sodium (Na24) from normal table salt. The isotope could now be used to replace natural radium ensuring some profits ${ }^{12}$.

Poillon was now eager to control the nascent isotope market. He offered Lawrence's «gadgets» to both Westinghouse and American Cynamid that considered producing cyclotrons for business purposes. More significan-

10. See also Turchetti, Simone. The invisible businessman. Patenting policies and practices in Italy in the 1930s. Historical Studies in the Physical and Biological Sciences. 2006; 37 (1): 153-172.

11. On the cyclotron and its functioning see Heilbron; Seidel, n. 5, chap. 2. See also Cathcart, Brian. The fly in the cathedral. How a small group of Cambridge scientists won the race to split the atom. London: Penguin; 2004, p. 193-196.

12. Lawrence, Ernest O. Method and apparatus for the acceleration of ions. US 1948384, issued 20.2.1934 (assigned to the Research Corporation). The corporation did not seek immediate profits, but rather redistributed economic rewards for future research. Heilbron; Seidel, n. 5, p. 102. In 1937, Lawrence also considered the prospects of radio-phosphorus (P-32) and radio-iron (Fe-59), which could be use to treat leukemia. Treatments of this kind generated a market ranging between $\$ 200,000$ and $\$ 500,000$ each year only in the U.S. Heilbron: Seidel, n. 5, p. 188 and 197. The most significant economic advantage of producing isotopes derived from lowering the soaring price of natural radium ( $\$ 75.000$ dollars per gram in the 1930s). On this see: Ullyett, B. Radioisotopes. In: Canada enters the nuclear age: A Technical history of atomic energy of Canada limited as seen from its research laboratories. Montreal and Kingston: AECL and McGill-Queen's University Press; 1997, p. 97. 
tly, he tried to harness control of patents describing high-tension devices becoming the assignor of another generator designed by Robert Van De Graaf ${ }^{13}$.

Poillon, however, did not foresee that the development of other isotope production methods could hamper his plans. In 1932 the Cavendish researcher James Chadwick had demonstrated the existence of neutrons; particles of neutral charge and mass comparable to that of protons ${ }^{14}$. Many groups across Europe now considered using neutrons in the transmutation of chemical elements. The Italian Enrico Fermi, professor of theoretical physics at the Physics Institute of Rome University, made it his chief research goal. The physicist had established a small research group including his former fellow scholar Franco Rasetti, and the youngsters Emilio Segrè, Bruno Pontecorvo, Edoardo Amaldi and Oscar D’Agostino. Although the group lacked funding and large particle-emitters, they started transmutation research with neutronemitting tubes filled with radon and beryllium. Fermi's early experiments in the first half of 1934 produced satisfactory results. But as Holton has noted, Fermi's research produced outstanding results when, the following autumn, he considered using blocks of paraffin, a hydrogenous substance, between neutron sources and target elements. By using paraffin (and other substances rich in hydrogen), chemical elements could be more efficiently radio-activated ${ }^{15}$.

Fermi's patron, Orso Corbino immediately insisted that the group filed a patent on the «slow neutrons» process, being adamant that the method had promise of industrial application ${ }^{16}$. Fermi sent applications to a number of

13. Van De Graaf, R. Electrostatic Generator. CA 355514, issued on 21.1.1936, (assigned to the Research Corporation and MIT). This was designed by mechanical engineer Robert Van de Graaff in collaboration with physicist Merle Tuve at the Massachusetts Institute of Technology and the Carnegie Institution in Washington. See Lassman, n. 5, p. 314 and Cathcart, n. 11, p. 196-200.

14. On Chadwick's work on the neutrons see: Hughes, Jeff. 1932: The annus mirabilis of Nuclear Physics? Physics World, Jul 2000, p. 43-48; Kröger, B. On the history of the neutron. Physis. 1980; 22: 175-190.

15. On Fermi's work see Holton, G. Fermi's group and the recapture of Italy's place in physics. The scientific imagination. Case studies. Cambridge, MA.: Harvard University Press; 1978, p. 155-198. Holton, G. The miracle of the two tables. Enrico Fermi, a piece of paraffin and the way towards nuclear fission. Times Literary Supplement. 11 Jan 2002, p. 12-13. Hydrogenous substances slow down neutrons to ideal energy levels for their absorption in element's nuclei. In this way they are far more effective in producing isotopes from chemical elements.

16. Fermi's wife Laura claims: «One morning (...) Corbino came into the laboratory (...). They were preparing to write a more extensive report on their experiments (...). Corbino became 
patent offices. One of Fermi's former students, Gabriello Giannini, had now moved to New York, where he had specialised in trading new inventions. When the Italians considered applying for patents abroad, they asked him for advice. Fermi's method was offered in licence to General Electric and Westinghouse, but it was the Dutch firm Philips that acquired a license. From October 1935, Philips started administering Fermi's patent in 14 European countries in exchange for $5 \%$ of deriving royalties. Two patents were also filed in the US and Canada, and assigned to Giannini's company ${ }^{17}$.

In 1935, the filing of patents in the US accentuated Fermi's competition with Lawrence. Fermi's group had synthesized the same isotopes that Lawrence had, and their patents listed about one hundred isotopes altogether that could be manufactured through their method. The Italians' chief problem was the efficiency of their neutron-source. Rasetti visited Berkeley to verify the cyclotron's efficiency, and found out it could generate 10 billion neutrons per second. Lawrence's daily output of radio-sodium emitted a quantity of $\gamma$-rays equivalent to $100 \mathrm{mg}$ of radium, far more than what the Italians could produce. Rasetti was aware that more powerful neutron sources (i.e. high-tension machines) were needed if the group were to rival Lawrence's method ${ }^{18}$.

incensed. —What? Do you want to publish more than you have already? (...) Are you crazy? Can't you see that your discovery may have industrial applications? You should take a patent before you give out more details on how to make artificial radioactive substances!»: Fermi, L. Atoms in the family. My life with Enrico Fermi. Chicago: The University of Chicago Press; 1954 , p. 101. Amaldi claims that «shortly after the discovery of the effect of hydrogenous substances he [Corbino] suggested that slow neutrons might have important practical applications and that it could be advisable to take out a patent on this work»: Amaldi, E. From the discovery of the neutron to the discovery of nuclear fission. Physics Reports. 1984; 111 : 154-160. On Fermi's patent see also Segrè, E. Enrico Fermi. Physicist. Chicago: The University of Chicago Press; 1970, p. 83-85.

17. Fermi, E.; Amaldi, E.; Pontecorvo, B.; Rasetti, F.; Segrè, E. Process for the production of radioactive substances. US 2206634. Filled 3 Oct 1935. Issued 2 Jul 1940 (assigned to Giannini \& Co.). Amaldi, E.; D'Agostino, O.; Fermi, E.; Pontecorvo, B.; Rasetti, F. and Segrè, E. Method for increasing the efficiency of nuclear reactions and products thereof. GB 465045. Filed 25 Oct 1935 (convention date (Italy): 26 Oct 1934), issued: 26 Apr 1937 (assigned to Philips). On the Philips' patent office see: Heerding, A. The history of N.V. Philips'Gloeilampenfabriken. Cambridge: Cambridge University Press; 1986. On 14 Oct 1935 Hijmans visited Rome to verify the method's efficiency and finalise the agreement with the Italians. Hijmans to: Fermi, 16 Oct 1935; Giannini to: Hijmans. 18 Nov 1935. Scatola 1. Fascicolo 2. Brevetto Neutroni, carte 34-35. CNA.

18. Fermi was extremely surprised as he estimated Lawrence's production in the range of the microcuries rather than millicuries. To convince the Italian, Lawrence sent him a millicurie 
In 1937 Giannini was dispatched to Britain to find parties willing to allow him to license their patented methods on high-tension devices. He met with Thomas E. Allibone, of the firm Metropolitan-Vickers, which owned a patent on a machine designed by the Cavendish's researchers John Cockcroft and Ernest Walton. Metropolitan-Vickers made an offer to take an «option» on Fermi's patent for a three-year period. As Giannini had already signed the contract with Philips, he was forced to turn the offer down ${ }^{19}$.

Whilst in Britain, Giannini also met the Hungarian Leo Szilard, another skilled «patenteer». By 1934, Szilard had developed a "chain reaction» process that he saw as pivotal to the transmutation of chemical elements ${ }^{20}$. Szilard designed a patent on his process. Giannini tried to negotiate an agreement on Szilard's patent because it claimed priority on a powerful neutron generator. But the Hungarian, using the Research Corporation as an example, claimed that he wanted to set up a similar organization. Writing to Fermi after the meeting, Giannini stressed that Szilard's proposal was unrealistic, and rejected it ${ }^{21}$.

Giannini left England knowing that the Italians could not secure control over the isotopes market. No patents" «pool» could be put together, and the

of radiosodium by post. Heilbron; Seidel, n. 5, p. 187.

19. Cockcroft, John D.; Walton, Ernest S. T. System for the voltage transformation of direct current electrical energy. US 1992908. Issued 26 Feb 1935 (assigned to Metropolitan-Vickers). On Giannini's negotiations see Allibone, T. E. Metropolitan-Vickers electrical company and the Cavendish laboratory. In: Hendry, J. ed. Cambridge Physics in the thirties. Bristol: Adam Hilger; 1975, p. 150-173.

20. Szilard, Leo. Improvements in or relating to the transmutation of chemical elements. GB 630726. Filed 28 Jun 1934. The method consisted of three parts: generation of neutrons to provoke reactions; separation of radioisotopes produced by the neutron process; and utilization of the heat liberated in the transmutation for energy purposes. Heilbron; Seidel, n. 5, p. 199-200. On Szilard's patents see: Lanouette, W. Genius in the shadow. A biography of Leo Szilard, the man behind the bomb. Chicago: The University of Chicago Press; 1992, p. 138 and Weart, Spencer; Szilard, Gertrud W., eds. Leo Szilard: his version of the facts. Selected recollections and correspondence. Cambridge, Mass.: MIT press; 1978, p. 41-43.

21. Giannini wrote that the plan for uniting forces failed because «he [Szilard] only wanted to take patents in countries in which the patent procedure was entirely secret, thus preventing some Central European Governments from knowing of his ideas and using them for militaristic purposes against other nations». Giannini considered the statement «quite odd», as at that time Szilard was probably one of the few who envisaged militaristic uses of atomic energy. Szilard to: Fermi. 13 Mar 1936 and Giannini to: Fermi. 17 Mar 1936. Scatola 1. Fascicolo 2. Brevetto Neutroni, carte 34-35. CNA. 
only possibility for the Italians was perfecting their neutron tubes ${ }^{22}$. But in 1939, it became clear that this was not an option either. The efficiency of the neutron tube that Philips had designed was still inadequate, whilst the cyclotrons had improved more rapidly. Moreover, medical applications of radio-nuclides had been very successful, but other applications of isotopes still did not generate a market large enough to consolidate patents' trading. Now pessimistic about the patent's prospect, Giannini sold the European patent to Philips ${ }^{23}$.

In 1939, Fermi's, Szilard's and Lawrence's methods still seemed too far from being industrially viable. Industrialists in Europe and America initially showed some interest in their processes, but this fizzled out due to the methods' limitations. Yet, the «turn of the tide» for the isotope industry and its relevant patents came with the war ${ }^{24}$.

\section{Patents, isotopes and the war}

During WWII, the design of nuclear piles allowed transferring isotope manufacture from the small scale of laboratory apparatus to the large scale of industrial production. Nuclear piles therefore enabled the use of existing methods at industrial level, and propelled their commercial profitability beyond the limitations of the pre-war years. However, during the war and after, new patent provisions contributed to hamper their commercial uses and virtually annihilated the commercial relations centred on industrial patents ${ }^{25}$.

22. Their European competitor was a little more successful. In 1936, Szilard assigned the European patent on the «chain reaction» to the British Admiralty. Its officers were happy to have the patent assigned to them, even though they did now know what to do with it. Heilbron; Seidel, n. 5, p. 205.

23. For $\$ 3200$. Of which $\$ 300$ were immediately divided between the inventors and $\$ 800$ were put aside by Giannini for future expenses. Giannini to: Segrè (copy to Fermi). 18 Apr 1939. «Segrè Emilio». Box 11, Folder 13. EFP.

24. As Lewis Strauss noted, isotopes were still something for «science-fiction fans». See Amaldi, $\mathrm{n}$. 16, p. 159.

25. See also Turchetti, S. For slow neutrons, slow pay. Enrico Fermi's patent and the US Atomic Energy Program. Isis. 2006; 97: 1-28. 
The chief reason for this was that isotope research overlapped the US atom bomb project ${ }^{26}$. Between 1940 and 1942, Fermi and Szilard, who had moved to the US before the war, participated in designing an experimental nuclear pile at the University of Columbia and the University of Chicago. The Chicago Pile 1 (CP-1) aimed at verifying the possibility of harnessing atomic energy, but the scientific principle of slowing neutrons down was also implicated in its functioning, as the use of the hydro-carbon graphite allowed nuclear reactions to occur. Fermi's process has since come to be known as the «moderator effect» owing to the fact that it regulates the moderators, i.e. those nuclear pile components that surround neutrons sources and targets to allow nuclear fission ${ }^{27}$.

By then the role that the process of nuclear fission played in the atomic energy research, as well as the transmutation of chemical elements, was becoming clearer. One uranium isotope, U 235, in certain conditions could fission generating a chain reaction process similar to that envisaged by Szilard in his patent. This process could release enormous amounts of energy, which made it an essential feature for atomic weaponry as well as for nuclear reactors. The process had implications for isotope production too; it allowed yielding greater quantities of neutrons, therefore producing isotopes on a large scale. Although many European and American investigators understood these implications, only the French physicist Frèdèric Joliot-Curie and his assistants Hans Von Halban and Lew Kowarski sought patenting the nuclear fission process before the war ${ }^{28}$.

As nuclear pile research was part of a military project, it was also embodied in new military provisions regarding industrial patents. In 1942, the US Office of Scientific Research and Development (OSRD) directed by Vannevar Bush, outlined a patent policy which effectively made anyone dealing with the uranium project dependant upon its control in the design

26. Named «Uranium project» in its early stages and then Manhattan Project from the location of the US army engineering division that took control of the project from 1943 (the Manhattan Engineering District).

27. On Fermi's work at Columbia and Chicago see Hoddeson, L.; Henriksen, P. W.; Meade, R. A.; Westfall, C. Critical assembly. A technical history of Los Alamos during the Oppenheimer years, 1943-1945. Cambridge: Cambridge University Press; 1993, Chap. 3; Maltese, Giulio. Enrico Fermi in America. Bologna: Zanichelli; 2005, Chap. 6.

28. Joliot-Curie; F. Von Halban, Hans; Kowarski, Lew. Improvements in and relating to the production of energy through nuclear fission of uranium. FR 971384. 16.1.195, Issued 30 Apr 1940. This patent however dealt exclusively with nuclear fission as a means of energy production, thus not considering isotope production. 
of new patents. Two new patents on the «neutronic reactor» were outlined under the new OSRD patenting regime and featured Fermi and Szilard as inventors. Owing to the military implications of atomic energy, these patents were placed under a «secrecy order», and safely kept by military authorities in the US patent office. Their issuing was ruled out until the mid-1950s therefore making their trading impossible ${ }^{29}$.

The patent system now put in place, affected ongoing research on isotope production. Since 1941 Lawrence had been in charge of the construction of a large cyclotron, aiming at separating by electromagnetism the isotope U235 from its carrier U238. The design of Lawrence's machine, the "Calutron» (California cyclotron) was outlined in another OSRD patent which was put under a «secrecy order» ${ }^{30}$. His method to produce the isotope U235 would prove less efficient than another method based on gaseous diffusion of U238. Designed by four scientists (John R. Dunning, Eugene Booth, Alfred Nier, and Aristide V. Grosse), it led to the filing of more secret patents ${ }^{31}$. In the same period, a new chemical element, plutonium (and its isotopes), was artificially synthesised and it would eventually prove a more valuable fissionable material than U235. The University of California researchers Emilio Segrè, Glenn T. Seaborg, Joseph Kennedy, and Arthur C. Wahl privately designed five patent applications, as well as one secret patent as OSRD employees ${ }^{32}$.

29. The OSRD had now «the power to determine the disposition of all rights in discoveries and inventions» for national defence purposes. See Senate Hearing on Atomic Energy, Atomic Bomb Patents. Bulletin of Atomic Scientists (BAS). 1946; 1: 10-11. The filed patents were Fermi, E.; Szilard, L. Neutronic Reactor. US 2708656. Filed: 19 Dec 1944. Issued: 17 May 1957 (assigned to the OSRD, and then the AEC); Fermi, E.; Szilard, L. Neutronic Reactor. US 2807581. Filed: 11 Oct 1945. Issued: 24 Dec 1957 (assigned to the OSRD, and then the AEC). The inventors received a symbolic compensation of one dollar for their contribution. Fermi filed other 18 patents during the Manhattan projects.

30. Lawrence, E. O. Methods of and apparatus for separating materials. US 2709222. Filed 9 Oct 1944. Issued 24 May 1955 (assigned to the OSRD, and then the AEC).

31. The inventors worked at the Universities of Columbia, Minnesota and Temple. Their research however did not produce a patent, but only a patent application.

32. Plutonium was produced by the transmutation of isotope $U 238$ in nuclear piles and several processes of chemical separation. Seaborg, G. T.; Segrè, E.; Kennedy, J.; Wahl, A.C. Transuranic elements, composition thereof and method of producing, separating and purifying same. US applications 637485; 637486; 637487; 637487; and 750175. Their «secret» patent was Seaborg, G. T.; Segrè, E.; Kennedy, J.; Wahl, A.C. Producing energy and radioactive fission products. US 2908621. Filed: 11 Dec 1945. Issued: 13 Oct 1959 (assigned to the AEC). 
When the Manhattan Project took off, scientists and industrialists agreed that all new patents produced in the project would become a property of the US government. However, the inventors considered that the patents filed before the project (and pivotal to its success) should be rewarded. Two days after the CP-1 experiment, Szilard was requested by military personnel to file a patent on the chain reaction process. But as a patent on the process had already been issued before the war, Szilard wanted to know the policy adopted on patents protecting «inventions made and disclosed before we had the benefit of the financial support of the government». Protracted negotiations produced little success as Szilard «limited the [US] government's payment to his actual expenses (...) plus a customary $\$ 1.00$ patent fee» ${ }^{33}$.

Patents which had implications for the production of isotopes also featured in bilateral talks between Bush and the British representatives of the Anglo-Canadian «Tube Alloys» (TA) project, which paralleled the Manhattan Project. In 1942, the need to ensure a monopoly on these patents led TA's administrators to discuss these matters with Bush, who however rejected the British proposals ${ }^{34}$.

On the whole, the war made it impossible for many investigators to effectively administrate their intellectual property rights. Yet Fermi and Segrè vigorously argued that patents fundamental for the completion of the Manhattan project, and filed before the conflict, should be compensated. After the war, Giannini's attorney, Lawrence Bernard, proposed that the OSRD buy the slow neutrons patent for about 900.000 dollars. And Bush stated that he was favourably disposed to close the deal ${ }^{35}$.

33. A settlement for the value of the chain-reaction patent itself, Szilard insisted, would be worth much more. Lanouette, n. 20, p. 254. See also Rhodes, Richard. The making of the atom bomb. New York: Penguin; 1986, p. 503.

34. New provisions giving Britain and the US exclusive reciprocal licensing for all patents were considered, but never adopted, presumably because the French patents on nuclear fission (and others on plutonium) were assigned to the TA Directorate. Gowing suggests that at that stage «Bush had blown cold over the whole question of patents» probably because he perceived the claims contained in the French patents as competing with those outlined in the Fermi-Szilard patents. Von Halban and Kowarski sold them in exchange for salaries more then twice higher then what they already received, and a promise of $14 \%$ of profits deriving from the exploitation of their patents. Gowing, Margaret. Britain and Atomic Energy, 1939-1945. London; 1964, p. 207-212.

35. Giannini to: Bush. 19 Oct 1945. Box 19. Folder 2. EFP. 
No compensation, however, was effectively executed. On 1 August 1946, the Atomic Energy Act allowed the establishment of the AEC, and made Bush's «promise» worthless. Section 11 (patents) of the act dictated that it was now the AEC which should compulsorily purchase the «atomic patents». But because the act's approbation was accompanied by political rows, it delayed the execution of section 11. A Patent Advisory Panel should have provided new regulations to implement it, but only completed its work by 1949. After that, a newly established Patent Compensation Board (PCB) started operating ${ }^{36}$.

These delays presented an annoyance especially for those who had invented the methods now used in the isotope industry, which by then had become more prosperous. By the summer of 1950, the AEC possessed a portfolio of 109 radio-elements. 15 of them were produced through cyclotrons, whilst the other 94 were produced in reactors using Fermi's process. In 1949, the number of isotope shipments abroad had tripled in respect to 1947 , reaching the number of 2,200 shipments. The inventors knew that the isotope industry was now offering growing economic opportunities, and felt that they should now have their fair share of profits ${ }^{37}$.

On the other hand, with the approbation of the McMahon Act, a new monopolistic regime controlling the isotope industry was put in place. Its establishment affected its technological development by restricting the free trading of its relevant patents. Far more worryingly, it also demanded the acquisition of existing atomic patents without however effectively executing it. Some inventors, like Szilard, accepted the new provisions because he had already negotiated claims with the OSRD. Others, such as Lawrence,

36. Section 11 was criticised and considered by many US Congressmen as «Soviet» in character, as it opposed liberalism and free-market, also violating the fundamental tenets of the patent system. On this see: Hewlett, Richard J.; Anderson Jr., Oscar E. The new world. A history of the US Atomic Energy Commission, 1939-1946. Berkeley: University of California Press; 1962, p. 513.

37. AEC. Isotopes. A three-year summary of US distribution, August 1949. Copy in Busta 57 Radioisotopi DGAE. MAE. The articles of Creager and Herran in this volume show that US exporting activities centred on isotopes did not respond to strictly commercial and financial reasons, as they were embedded into a political and diplomatic strategy aiming at boosting the peaceful applications of the atom. However, this does not mean that those who with their inventions had contributed to lay the foundations of this exporting activity felt less bitter about these delays. 
never claimed compensation ${ }^{38}$. But in some cases, such as that of Fermi and his associates, the delays led to important legal controversies, as we shall now see.

\section{The Patent Compensation Board (PCB) activities}

If WWII contributed to make the business of patents describing isotope production more contentious, the Cold War made it a subject of court cases. The PCB proceedings reflected not only the growing power of the AEC in administering intellectual property rights, but also overlapped new anxieties deriving from security concerns and domestic anti-communism in the US. Even so, its administrators knew that they now had the «upper-hand» over the claimants. Between 1950 and 1976, the board docketed 38 cases of compensation, of which eleven related to isotope production patents; three to isotope separation methods; four to the slow neutron patent; and one on the nuclear fission process. Yet, for most cases its officers denied that any compensation should be given ${ }^{39}$.

For example, in the 1950s the French Atomic Energy Commission gave a mandate to an affiliated company, the French American Neutronic (FAN) to administer the legal cases associated with the French fission patents. The FAN first appealed against the US patent office's decision to reject its five pending patents. The District of Columbia Civil Court and its Court of Appeal examined the company's petition, but could not pass judgement

38. Presumably Lawrence felt that his wartime work with the cyclotrons ought to be considered as his personal contribution to the war effort. Heilbron and Seidel suggest that Lawrence and Poillon never fully appreciate the potential of cyclotrons as isotope producing devices, and when in 1951 the production and sale of isotopes finally took off, Lawrence's old patent expired and was not renewed. By 1970 the production of isotopes through cyclotrons exceeded \$ 3 million. Heilbron; Seidel, n. 5, p. 166.

39. These were McClellan, Cyril E. Isotope separation. US patent application n. 469847. Filed 22 Dec 1942 (docket n. 4); Schultz, Helmut W. Multiple Effect Centrifugation Process and apparatus. US patent application n. 459634, filed 25 Sep 1942 (docket n. 5); and Dunning, J.; Booth, E.; Nier. A.; Grosse, A. US patent application n. 316,892 (docket n. 24). Giannini's original application (docket n. 2). The four claims associated with the slow neutrons were Giannini's second application (docket. n.11); a Philips' application (docket n. 16); and the application by Emilio Segrè, Glenn T. Seaborg, Joseph Kennedy and Arthur C. Wahl (docket 7). The French case was CEA (docket n. 18), US patent applications n. 328180; 328372; 666182; and 666183 . 
before 1960. In the meantime, the FAN also filed a compensation claim with the PCB, which however could not be assessed because of the pending court decision. In 1960 the petition was withdrawn in an attempt to facilitate discussions with the PCB, who however, rejected the claim. The claimants appealed again to the District of Columbia Court but without success ${ }^{40}$.

Similarly, the compensation claim on the patent application describing the gaseous diffusion process to separate isotope U235, was not successful. In 1959, the inventors' new association, the Basic Science Foundation, filed an application in which they claimed an award of $3 \%$ on the value of all U235 produced in the US, or $6 \%$ of all the capital value of all plants producing U235. Their claim was rejected as well ${ }^{41}$.

Only two applications were successful: Giannini's application (docket 2 ) and the application on the plutonium patents (docket 7). Even these cases, however, can hardly be seen as triumphs for the claimants, as they came after taxing proceedings, which produced more exasperation than royalties.

A crucial role in the PCB proceedings was played by the Office of General Counsel (OGC) which set out the board's legal defence. In 1949, the OCG's lead attorney, Bennett Boskey, reported his legal comments on Giannini's application. He denied the use of the slow neutrons method in the production of isotopes, or plutonium for atomic weapons. Boskey also stressed that some claimants could not be compensated because of their foreign nationality. He finally suggested that Fermi was in a "conflict of interests» as by then he was a member of the AEC General Advisory Committee (GAC). Boskey's response certainly looked ungenerous to the applicants especially in the light of Fermi's contribution to the American war effort. Why did Boskey reject Giannini's claim? ${ }^{42}$.

40. Gilguy, C. A good example of protection in the nuclear field: The story of the fundamental patents of Joliot's team. Library. UKAEA Research Group. Oct 1963 (copy translated by O. S. Whitston).

41. Nuclear Patents Controversy. BAS. 1952; 8: 48. In 1956, the four scientists filed a court suit, which however was never settled. In 1971, the suit was dropped when the scientists received from the AEC a scientific «award»» of $\$ 30,000$ each. The award according to an AEC spokesman was intended as a means to «quietly» settle their claims out of court. Scientists end suit and receive honors. New York Times. 13 Jul 1971.

42. Boskey, B. (OGC). Response to the Application of G. M. Giannini and Company, Inc., AEC-PCB, Docket No. 2, 6 Jun 1949, copy in Neutron patent. Scatola 2. Brevetto Neutroni. Fascicolo 2, CNA. The depiction of a conflict of interests exasperated Fermi to the point that he considered whether to leave the GAC. He wrote to Segrè that «under these circumstances I am seriously 
The security hysteria associated with the spreading of domestic anticommunism certainly played a role in these decisions. Section 10 of the Atomic Energy Act allowed the Federal Bureau of Investigation (FBI) to check AEC personnel. And the AEC administrators had been very eager to accommodate the dictates of Section 10 by checking security records even for cases where individuals were not employed by the Commission. As the applicants for compensation could be witnesses in legal proceedings, their FBI records needed checking too ${ }^{43}$. In this way, they became aware that the FBI had put one of the applicants, Bruno Pontecorvo, in its list of communist suspects. One may even speculate that the AEC administrators considered that an immediate settlement would pave the way to controversy. If the news about Pontecorvo's communist relations were to become public, then the decision to compensate him would have exposed the Commission to political attacks ${ }^{44}$.

considering whether I should not resign from the GAC». Fermi to Segrè, 9 Jan 1950. Box 19. Folder 4. EFP. In 1952 the attorney Hector Holmes of Fish, Richardson \& Neave, of Boston, Massachusetts was given mandate by the PCB to provide external advice on the settlement of docket n. 2. He claimed: «lt seems to me that the Board, or any tribunal before whom this might come on appeal, would view the Fermi invention and weigh the matter of award with generosity. Here we have one of the important discoveries in this vital field and a product of the most highly skilled research. I believe that the feeling would be wide spread, both in the world of science and industry, and with the public, that Fermi should be generously compensated». See «Hector Holmes's opinion» 23 Sep 1952, Appendix A in Anderson, Roland A. (Chief, Patent Branch); Smith, Wilbur F. (Of Counsel); Holton, William B. Memoranda and documents as to settlement. In: Patents vol. 1. Box 30, Folder 6. AEC Papers. NARA (I am truly thankful to Angela Creager for providing me with a copy of these papers).

43. Restrictions 5.B.i and 5.B.ii in Section 10 «Control of Information» of the Atomic Energy Act allowed the FBI to check and provide the AEC administrators with information on «character, association, and loyalty» of individuals. Ungar, Sanford J. FBI. Boston: Little, Brown and Co.; 1975, p. 90. PCB regulations stressed that the Board «may issue any general and specific order, directive, or further regulation which it determines to be appropriate pursuant to Section 10 of the act to assure the common defense and security» (General Provision 80.4). And that «in the conduct of hearings the Board shall ensure compliance with the security regulations» taking «whatever step it may deem appropriate» (Hearing, Provision 80.42.g). AEC General rules of procedures on applications for determination of reasonable royalty fee, just compensation, or grant of award for patents, inventions or discoveries. In: US Federal Register. 8 May 1948, p. 2487-2488. On FBI checks in the context of the AEC fellowship programs see Wang, Jessica. American science in the age of anxiety. Scientists, Anticommunism and the Cold War. Chapel Hill: The University of North Carolina Press; 1999. On security anxiety about atomic patents see the article of Angela Creager in this volume.

44. In 1942, an FBI report had indicated that its agents had broke into Pontecorvo's house when he was living in Tulsa (Oklahoma) and found Communist literature and correspondence with the 
In the summer of 1950, Giannini and Bernard (who were unaware of these pending security issues) resolved to file a petition with the US Court of Claims. They now claimed 10 million dollars for the patents past infringements and future uses ${ }^{45}$. But Bernard's strategy did not pay off. Since January 1949, Pontecorvo had worked at the UK Atomic Energy Research Establishment (AERE), which also employed the «atom spy» Klaus Fuchs. Following investigations at the AERE, in the summer 1950, he mysteriously disappeared and fled to the Soviet Union ${ }^{46}$.

His departure jeopardised Bernard's plans as Pontecorvo's flight could now be interpreted as casting a shadow on the claimants' political allegiance. The Italian physicists in the US had to face accusations over the disappearance of their colleague. Giannini wanted to withdraw from the court case, even if he eventually reversed his decisions ${ }^{47}$. The inventors instructed Bernard to seek a settlement at any cost. The PCB's administrators could now see the Pontecorvo case as a chance to bargain on the final settlement. In 1951 an offer of settlement for just 450.000 dollars was submitted. In 1953, it was finalized for 300.000 dollars ${ }^{48}$.

The settlement concluded the controversy on Fermi's patent in the US. But — as Bernard noticed - the payment was an «arbitrary figure arrived at

French physicist Joliot-Curie. In 1949 another report revealed the existence of links in the late 1930s between Pontecorvo, Italian Communist Party members, and two Italian scientists now living in the US. The content of this report is still not available through official FBI records. But can be known through MI5 records available from 2005 (especially The security aspects of the Pontecorvo Case. KV 4/242, NA). At no time the FBI evidence gathered was attached to the official PCB documentation because considered harmful to national security. See also Boskey, B. Inventions and the Atom. Columbia Law Review. 1950; 50: 433-447.

45. Giannini to: Fermi. 24 Aug. 1950. Neutron patent. Scatola 2. Brevetto Neutroni. Fascicolo 2. CNA.

46. See also Turchetti, S. Atomic secrets and governmental lies. Nuclear Science, policy, and security in the Pontecorvo case. British Journal for the History of Science. 2003; 36: 404-405.

47. He was even more worried because he was a contractor for the US Army. His statement read: «I am today instructing my attorney to eliminate and disinvest my company of any interest in the $\$ 10,000,000$ damage suit (...) This action is a result of the surprise and shock resulting from the amazing disclosure that Bruno Pontecorvo (...) has reportedly disappeared into Russia under circumstances that are highly questionable (...) I am an American citizen first, and my interests and interests of my company are concerned primarily with the principles of freedom and democracy». Giannini press release. Copy in Box 19. Folder 7. EFP.

48. The AEC Meeting 810 on 28 January 1952 led to the approval of the settlement proposal about Giannini \& Co. (decision AEC 289/3). See Anderson; Holton, n.42. Pontecorvo's share was never given to the claimant. It was put in frozen bank account controlled by the US Treasury as the Italian physicist was officially «missing». 
for the purpose of settlement» ${ }^{49}$. In fact, the official PCB documentation shows that the patent's private value was far higher than anything Giannini and the other Italians had in mind. In order to avoid paying it, the PCB officers addressed a number of problems that they claimed made it impossible to calculate the patent's value. The reality was that they could bargain on their position of privilege, which the Pontecorvo case had now further strengthened.

In calculating the patent's value, the PCB officers focussed on the costs associated with the production of plutonium and isotopes on both small and large scales during the Manhattan Project and the AEC regime respectively. But considering the production of plutonium should have led the Commission to award the amount requested by Giannini. In fact, their memoranda highlighted that «even if a one percent or less than one percent figure [my emphasis] were employed the sum would far exceed the proposed figure for settlement [i.e. \$ 1,9 million]» 50 .

Establishing the patent's validity was another significant problem that the PCB administrators claimed to have encountered. For example, the patent claimed that the neutrons were slowed down to an «average energy of not more than a few hundred electron volts», which made the PCB officers wonder whether this was exactly the energy of thermal neutrons in piles. The PCB's general manager, William Anderson, sought advice from Argonne and Oak Ridge National Laboratories. The technicians there replied that it «would involve months of calculations, aside from any practical experimentation» to understand the difference between what the patent stated and the effective process occurring in piles ${ }^{51}$. Anderson could only

49. It did not represent the considered judgement of the parties involved or the actual value of the patent. Bernard to: Gray, Ross G. (of Herridge, Tolmie, Gray and Coine, Ottawa, Canada). 12 Nov 1954. In: Brevetto Neutroni. Fascicolo 2. CNA.

50. «In fact, although there is no reason why the Board should exceed such requested amount, it is believed that they could grant an award in excess of that amount in the basis of damages for intentional infringement with knowledge of the existence of an outstanding patent. If one were to consider what would be a reasonable royalty there would have to be taken into consideration not only the cost of reactors per se, multiplied by the cost of the time of research personnel, but also an attempted estimate of the percentage value of the Fermi et al. patent as regards the reactor program». Analysis of infringement by the commission and its predecessors. Manhattan District of Fermi et al. patent. Appendix B. p. 14. In: Anderson; Holton, n. 42. .

51. Moreover, «in a reactor the range of energy employed would run the gamult (sic) of very fast to very, very slow, with most neutrons being slowed down to a specific limit which might 
conclude that because of these complications deriving from assessing its value and validity, the patent had more «nuisance value» than merits ${ }^{52}$.

Emphasizing the «nuisance value» of Fermi's patent clearly helped the PCB to get good value for money. The external advisor who commented on the final PCB reports stressed the sum requested did not shock «its sensibilities» and that the final award was «a very favorable one» for the Commission, one which they «should not hesitate to accept» ${ }^{53}$.

One year after the settlement of Fermi's patent, the PCB case on Seaborg et al. patent applications on plutonium (docket 7), was also successfully completed with the payment of $\$ 400,000^{54}$. On the whole, the AEC payments to acquire intellectual property rights on isotope production patents consisted of $\$ 700,000$. Considering that the industrial uses of isotopes helped the Commission to save as much as \$ 500 million in 1957, and by 1960 the isotope industry would pay the whole AEC programme, the costs associated with patents counted for less than $1 \%$ of the profits deriving from this industry ${ }^{55}$.

be considered a norm. If by average energy was meant the bulk of the range in which the neutrons of a reactor were operated they would not committee themselves to say they would or would not have energies of «not more than a few hundred electron volts». Moreover, maintaining a defense based upon the energy ranges indicated in the patent required someone of Fermi's scientific stature witnessing against him in proceedings. And the PCB administrators could hardly find someone willing to do so. «Very few scientists in this country are of the stature of Dr. Fermi, and of those considered to be his peers, all would hesitate to contradict any interpretation of Dr. Fermi (...) in view of his position as Nobel Prize winner». Review of Defenses set forth in the response of the OGC in application Docket n. 2. Appendix C. In: Anderson; Holton, n. 42.

52. «There has been no commercial use, no royalty payments, there is no breakdown of cost figures for research or production or even estimates as to parts of the Commission program in which the Fermi et al. disclosure has been employed. It would be a monumental task to attempt to secure such figures, and at most they would be in general only qualified estimates [...]. The subject matter would entail time-consuming declassification and security problems and take considerable time to hear [...]. It is believed that the services and costs would conservatively come to at least $\$ 150,000 »$. Anderson, n. 51, p. 12

53. Hector Holmes's opinion. 23 Sep 1952, Appendix A in Anderson; Holton, n. 42.

54. The inventors had secured British patents on their invention, which threatened the AEC control of foreign rights. Thus, a further compensation of $\$ 100,000$ was allowed for the acquisition of these rights. Proposed Settlement of Claim of Docket 7. Report to the General Manager by the OGC. In: Patents vol. 1. Box 30. Folder 6. AEC Papers. NARA.

55. See Néstor Herran's article in this volume. 


\section{Britain and Canada}

The AEC was not alone in considering the control of the isotope market through its relevant patents. Britain and Canada had been far less strict in the management of atomic patents, as their nuclear agencies never considered seizing them despite the existence in these countries of legislation similar to the US Atomic Energy Act.

However the legal circumstances that allowed the settlement of Fermi's US patent determined similar issues in Britain and Canada. In the pre-war years Philips had secured an exclusive right to exploit Fermi's process in Europe. Thus, its managers were most scorned by the recent settlement, and filed a claim before the PCB (docket 16), which was, not surprisingly, rejected. This led the Philips's managers to activate negotiations with the United Kingdom Atomic Energy Authority (AEA) that from the late 1940s produced isotopes at the nuclear facilities of AERE, Harwell and Amersham, also trading them in Europe. Philips saw the AEA as a potential target because since 1947 the agency had become the chief exporter of isotopes, trading up to $40 \%$ of its current production ${ }^{56}$.

In 1948 the Philips director, Hendrik Casimir, alerted Harwell's director, John Cockcroft, that the AEA should pay royalties for its isotope production. Casimir had also stressed that Philips intended to set up a commercial partnership with the AERE, and would grant a free licence in exchange for «some commercial concessions». The AEA already exported isotopes in twelve countries and Cockcroft felt that there was no need of a foreign agent mediating the agency's commercial activities. Moreover, the AEA's patent experts argued against the validity of Fermi's British patent and in 1950, its counsels shared ideas with Boskey and Anderson on their respective defences 57 .

56. Fermi Patent. Meeting of 6 Jun 1948. In: Infringement Action to Fermi Patent n. 465045. AB 16/2682. NA.

57. British patent experts argued that: «The main claim is wide enough to include the elements lithium and boron both of which are neutron absorbing materials incapable of giving the desired result». Griffiths, W. to: Cockcroft. 22 Jun 1949, and Anderson (PCB) to: Griffiths, A. W. (Ministry of Supply). 20 Feb 1950. In: Infringement Action to Fermi Patent n. 465045. AB 16/2682. NA. Boskey visited Harwell in February 1950 when a tripartite meeting was organized on declassification matters. He figured as the AEC leading counsel in charge to ratify new provisions regarding declassification. But he also discussed patent matters with Cockcroft. 
In that year Philips succeeded in having Fermi's patent extended for the following 6 years, which represented a major blunder for the AEA. Following the 1953 settlement between Giannini and the AEC, Philips filed a suit against the AEA. However, in 1956 the AEA and Philips resolved to settle the case without further acrimony. Philips now accepted an offer of compensation that was estimated by the press to be in the range of $£ 10,000$. The offer also entailed a commercial partnership on isotope trading, but its details were not disclosed to the press ${ }^{58}$.

By contrast, no compensation was obtained by Fermi and his associates in Canada, where all atomic energy matters were administered by an Atomic Energy Control Board (AECB) ${ }^{59}$. Since the times of Tube Alloys, the Canadians had successfully developed new reactor technologies at a new nuclear station in Chalk River. This fuelled exporting activities centred on cobalt-60 and 50 other isotopes marketed through the AECB Commercial Products Division (CPD). From the 1950s to the 1970s, these activities ensured profits of several million dollars ${ }^{60}$.

In Canada both patents originally filed by Fermi and his co-workers had been issued, thus extending the validity of their claims. In 1954, Franco Rasetti, who represented the inventors from 1950 onwards, was pessimistic about the AECB's attitude towards their claim, but also aware that the successful conclusion of the US case worked to their advantage ${ }^{61}$.

58. Threadgold, T. D. Chartered Patent Agent, to: Cockcroft. 14 Jun 1954. In: Infringement Action to Fermi Patent n. 465045. AB 16/2682. NA. By then, Philips also agreed with the AEA that the British patent was not as «detailed and clear-cut» as its US equivalent which justified the significant difference in value between the compensations in the US and the UK respectively. Casimir, H.: to Rasetti. 28 Mar 1961. In: Lawsuit over 1934 Moderator Patent. AB 16/3760. NA.

59. The first Canadian patent was Fermi, E.; Rasetti, F.; Amaldi, E.; Segrè, E.; Pontecorvo, B. Radioactive Isotope Production. CA 407558. Issued: 22 Sep 1942. The second was Fermi, E. Radioactive Isotope Production. CA 407559. Issued: 22 Sep 1942, (assigned to Giannini \& Co.). This patent had been filed in the US patent office too, but it was rejected in 1940.

60. On the Canadian atomic establishment see: Bothwell, Robert. Eldorado. Canada's National Uranium Company. Toronto: University of Toronto Press; 1984, and Bothwell, Robert. Nucleus. The history of atomic energy of Canada Limited. Toronto: University of Toronto Press; 1988. On the profits deriving from the isotope industry see Ullyett, n. 12, p. 102.

61. Rasetti, F. Meeting in Washington. 27 Oct 1953. Brevetto Neutroni. Fascicolo 2. CNA. The first Canadian patent was Fermi, E.; Rasetti, F.; Amaldi, E.; Segrè, E.; Pontecorvo, B. Radio-active isotope production. CA 407558. Issued: 22 Sep 1942. The second was Fermi, E. Radio-active isotope production. CA 407559. Issued 22 Sep 1942, (assigned to Giannini \& Co.). This patent had been filed in the US patent office too, but it was rejected in 1940. 
An attorney of Ottawa, Ross G. Gray, was made responsible for the legal case. In the early months of 1955, Gray met the AECB representative proposing an amicable settlement, but no offer was put forward. Gray's proposal to settle the case for a sum between 150 and 300 thousand US dollars was also rejected. In 1956, as the AECB continued to avoid offering compensation, a suit was eventually filed with the Exchequer Court of Canada. The court case continued for many years, and in 1962 the court rejected the claim and confiscated the patents ${ }^{62}$.

\section{Conclusions: the contentious business}

The statistical analysis in the first part of this paper shows that the isotope industry was typified by feeble patenting activities especially when, by contrast, the industry as a whole was thriving, and its sales and publications almost exponentially increased. The historical analysis in the second part of the paper puts these anomalous data in context by showing that the patents trading followed a dynamic which was opposite to that of the isotope business. The development of this trade took place before the isotope business became profitable. When in the post-war years, the expansion of the isotope industry made it more lucrative, the free market of the isotope production patent became impossible, thus ensuring virtually no revenues to inventors and patents owners. This made them more resistant to file new patents effectively taking patents on isotope production out of the traditional commercial activities associated with patents trading.

Moreover, from the 1940s onwards, industrial patents were not used to direct corporate strategies in the isotope industry, but in order to define a new monopolistic system of production and distribution centred on governmental nuclear agencies. This was chiefly because the war presented those who administered atomic matters with a new problem: similar patented processes could be used to produce fissionable materials

62. Bernard to Gray 12 Nov 1954 and Gray to: Bernard. 25 Mar 1955. Brevetto Neutroni. Fascicolo 2, CNA. According to Rasetti: «In Canada they always absolutely refused to give us anything, they confiscated the patent, they were the nastiest government we had to deal with (...) they were unpleasant when we asked for compensation (...) it was the worst government we had to deal with». Rasetti, Franco. Interview with John Kennedy; 1966. Fermi Documentary Film Collection. Harvard Project Physics. Box 1. Background research materials and interviews. Niels Bohr Library. AlP. Maryland. 
for atomic weapons as well as isotopes for peaceful applications. This led them to consider provisional wartime measures that forbid their free trading. After the war, the McMahon Act consolidated this ban by giving the AEC monopolistic rights over patents. Thus, new provisions centred on patents, were effectively used as tools of science and technology policy to redress the present and future of the isotope industry. This paper is not suggesting that this policy responded to a precise market strategy aiming at profiting from the isotope industry. The new patent provisions were rather a consequence of a new approach to the management of nuclear matters as whole. Nonetheless, by the early 1950s, the economic advantage associated with the new patent provisions became clearer. To a certain extent they also informed the PCB activities making its administrators more resistant to recognise the intellectual property rights of inventors who had filed patents on isotope production processes.

Even so, the McMahon Act failed to ensure a successful administration of patents. And if it disappointed inventors, it did not please industrialists either. In 1954, the Act was revised in order to favour greater involvement of private entrepreneurs in the nuclear industry. In 1956, the AEC decided to waive rights on inventions on isotopes to allow improving R\&D activities ${ }^{63}$. But even after the McMahon act was amended, the patent provisions continued to be in place which explains why no patents on isotope production were issued in the US for a long time.

The legal and financial cases that defined the settlement of Fermi's patent in the US, Britain and Canada produced different outcomes, but they possessed some similarities. The nuclear agencies could develop new legal strategies to undermine the significance of the patent and thus, compensate for less (or not compensate at all) the claimants. Cleverly exploiting the position of power that the war had provided them with, they could now use it to monopolistically control the isotope business. Fermi's patents possessed a private value that overwhelmingly exceeded what their owners could effectively obtain. Clearly, the fact that the AEC was granted control over the isotope industry played to the advantage of those in the PCB who had to purchase these patents, as they could now dispute their private value. Other motives were in play that could in turn help them to seek

63. AEC to Waive Rights to Inventions or Discoveries Resulting from Use of Materials Made Available Generally. 18 Sep 1956. In: Patents. Folder 2. Box 31. AEC papers. NARA. 
more advantageous buying conditions, including the consequences deriving from the security concerns that typified the spread of anti-communism in the US. The case was different for other countries, such as Britain and Canada, where the legislation adopted was less restrictive. However, the legal controversies that opposed the AEA and Philips in Britain, and the AECB and Fermi's associates in Canada show that filing petitions was of little avail to the inventors and patent's owners.

The case of Fermi's patent also offers an important comparative example of how the transition from corporate to monopolistic control of the isotope industry affected patents trading. Before the war, the agreement with Philips ensured that $5 \%$ of deriving royalties would be given to the inventors. The AEC representatives could bargain favourable conditions that diminished this value to less than $1 \%$. Thus, whilst the isotope market produced growing economic strength to its isotope producers, it increasingly diminished the possibility of inventors and patent's owners getting a fair share of this wealth. 